Науковий вісник НЛтУ України

Scientific Bulletin of UNFU

http://nv.nltu.edu.ua

https://doi.org/10.15421/40290115

Article received $16.01 .2019 \mathrm{p}$.

Article accepted 28.02.2019 p.
ISSN 1994-7836 (print)

ISSN 2519-2477 (online)

$@ \bowtie$ Correspondence author

S. I. Matkovska

matkovcka@ukr.net

удк 630.27:632

С. І. Матковська, М. М. Світельський, О. В. Іщук, Т. В. Пінкіна, М. І. Федючка, В. Д. Соломатіна

Житомирський національний агроекологічний університет, м. Житомир, Украӥна

\title{
ЕКОЛОГІЧНА РОЛЬ ПРЕДСТАВНИКІВ РОДУ ACER L. У ЗЕЛЕНИХ НАСАДЖЕННЯХ МІСТА ЖИТОМИР
}

Досліджено еколого-естетичну роль дерев видів: клен ясенелистий (Acer negundo L.) та клен гостролистий (Acer platanoídes L.) poдy Acer L. у зелених насадженнях Житомира. Визначено, що фітосанітарний стан дерев клена гостролистого (Acer platanoídes L.) у 83 \% досліджених екземплярів добрий, у $12 \%$ виявлено механічні пошкодження, 5 \% дерев перебувають у пригніченому та фаутному станах. 3'ясовано, що дерева клена гостролистого (Acer platanoídes L.) основну масу дрібного коріння накопичують у верхньому 30-сантиметровому шарі грунту, на глибині 0-10 см зосереджено до 38 \% фізіологічно активного коріння, на глибині 10-20 см - до $26 \%$, на глибині 20-30 см розташовується до 17 \% фізіологічно активного коріння. Коренева система клена гостролистого (Acer platanoídes L.) у віці 30-35 років проникає в грунт на глибину до 90 см, бокові корені, які розташовуються ближче до поверхні, - розгалужені та добре розвинені. Більшість екземплярів клена гостролистого в зелених насадженнях Житомира мають високі декоративні властивості, повною мірою виконують фітомеліоративні функції, сприяють очищенню атмосферного повітря від пилу, газів та знижують шумове навантаження. Встановлено, що дерева клена ясенелистого (Acer negundo L.) в групових насадженнях перебувають у задовільному стані, за фітосанітарними показниками 52 дерева із 56 є в доброму стані, мають високу декортивність та естетичну привабливість. Водночас відзначено раннє омертвіння скелетних гілок у дерев у 25-30 років та формування порослевих насаджень із сплячих бруньок, що спричиняє здичавіння та інвазію клена ясенелистого (Acer negundo L.) в зелених насадженнях Житомира.

Ключові слова: екологічна роль; естетичний вигляд; клен ясенелистий (Acer negundo L.); клен гостролистий (Acer platanoídes L.); інтродукція.

Вступ. Представники родини Клен (Acer L.) переважно інтродуковані до України з Китаю, Японії, Кореї та Америки. Для озеленення населених місць в Китаї їх використовували ще у XVI-XVII ст. В Японії клени використовують для озеленення урбокомплексів із XVIIXVIII ст., що набуло значної популярності в озелененні поряд із сакурами в сучасних індустріальних містах цієї країни. На американському континенті клени є аборигенними видами, оскільки клен цукровий $є$ символом Канади, а також вони значно поширені в Сполучених Штатах Америки. На сьогодні в цих країнах культивується понад 90 декоративних видів кленів (Kalinichenko, 2003). Інтродукція кленів до України розпочалась у XIX ст. зі східно-азіатських видів. Пізніше до України було завезено американські види кленів. У су-

часному озелененні нашої держави використовують понад 30 декоративних видів кленів. На сьогодні найбільшого розповсюдження в зелених насадженнях Житомира набули клен ясенелистий (Acer negundo L.) та клен гостролистий (Acer platanoídes L.).

Клен ясенелистий (Acer negundo L.) досягає висоти 15-20 м, має широку крону діаметром 10-14 м із ламкими гілками оливково-зеленого кольору зі сизим нальотом. Кора в нього сіра, у старих дерев вона буро-коричнева, з продовгуватими тріщинами. Інтродукований до України у 1809 р. І. Н. Каразін привіз зі США і Канади насіння клена, з них в Основ'янському акліматизаційному саду під Харковом виросла перша генерація дерев клена ясенелистого. Рослини швидко акліматизувались до кліматичних умов та швидко дали життєздатне по-

\section{Інформація про авторів:}

Матковська Світлана Іванівна, канд. с.-г. наук, доцент, кафедра біоресурсів, аквакультури та природничих наук. Email: matkovcka@ukr.net; https://orcid.org/0000-0002-8019-5498

Світельський Микола Михайлович, канд. с.-г. наук, доцент, в.о. завідувача кафедри біоресурсів, аквакультури та природничих наук. Email: svitmm71@ukr.net; https://orcid.org/0000-0003-1501-4168

Іщук Оксана Василівна, канд. с.-г. наук, доцент, кафедра біоресурсів, аквакультури та природничих наук. Email: ischuk_o@ukr.net; https://orcid.org/0000-0002-8993-8366

Пінкіна Тетяна Василівна, канд. с.-г. наук, доцент, кафедра біоресурсів, аквакультури та природничих наук. Email: pinkinatv61@gmail.com; https://orcid.org/0000-0001-9443-8406

Федючка Микола Ілліч, канд. с.-г. наук, доцент, кафедра біоресурсів, аквакультури та природничих наук. Email: mif_1963@ukr.net; https://orcid.org/0000-0001-5150-9147

Соломатіна Валентина Дмитрівна, д-р біол. наук, професор, кафедра біоресурсів, аквакультур та природничих наук. Email: evgeniya.solomatina@sekt.kiev.ua

Цитування за ДСтУ: Матковська С. І., Світельський М. М., Іщук О. В., Пінкіна Т. В., Федючка М. І., Соломатіна В. Д. Екологічна роль представників роду Acer L. у зелених насадженнях міста Житомир. Науковий вісник НЛтУ України. 2019, т. 29, № 1. С. $70-73$.

Citation APA: Matkovska, S. I., Svitelsky, M. M., Ishchuk, A. V., Pinkina, T. V., Fedyucka, M. I., \& Solomatina, V. D. (2019). Environmental Role of Representatives of Acer L. in Green Approximates of Zhytomir. Scientific Bulletin of UNFU, 29(1), 70-73.

https://doi.org/10.15421/40290115 
томство 2-го покоління. На початку XX ст. вид набув популярності в Естонії, Латвії, Польщі та інших країнах Свропи (Logginov, 1989).

Клен гостролистий (Acer platanoídes L.) - листопадне дерево висотою 12-28 м з широкою, густою кулястою кроною. Кора молодих дерев гладка, сіро-коричнева, з віком темніє до майже чорної і покривається довгими, вузькими поздовжніми тріщинами. Межа природного ареалу проходить вздовж берега Фінської затоки, через міста Макіївка Донецької обл., Запоріжжя, Інгулець Миколаївської обл., Березівку Одеської обл. та Кишинів. Медоносна й декоративна рослина. Клен гостролистий високопродуктивний весняний медонос, під час цвітіння 31 га можна зібрати понад 200 кг меду (Kochno, Dorochenko \& Chyprina, 1975).

Аналіз останніх досліджень. Високий рівень застосування кленів в озелененні та лісовому господарстві привертає увагу науковців до екологічних, естетичних, біологічних, хімічних, фізіологічних та інших властивостей представників роду Клен (Acer L.). Одним iз перших вивчав клени Микола Арсенійович Кохно, в працях якого відзначено високий рівень акліматизації переважної більшості інтродукованих гібридів та сортів кленів генеративного походження (Kochno \& Kuznetcov, 2000; Kochno, 1967, 1970). Завдяки таким характеристикам клен ясенелистий (Acer negundo L.) набув значного поширення у населених місцях України.

3 другої половини ХX ст. дослідники відзначають здичавіння (натуралізацію) клена ясенелистого (Acer negundo L.) на більшій частині території його вторинного ареалу. Популяції клена ясенелистого в 1990-х роках відзначено в Норвегії, Польщі, Німеччині, Литві, Естонії, Росії. Натуралізація відбувається в антропогенно порушених місцях: на берегах річок, вздовж залізниць, у старих парках, на пустирях, у занедбаних насадженнях, лісозахисних і вітрозахисних смугах (Kochno, 1967). Водночас дослідники відзначають високий ступінь стійкості клена ясенелистого (Acer negundo L.) до несприятливих екологічних чинників міського середовища. Серед науковців немає єдиної думки про користь або цілковиту шкоду клена ясенелистого (Acer negun$d o$ L.), саме тому цей вид викликає підвищену увагу та потребує проведення комплексних науково обгрунтованих досліджень із використання в озелененні урбокомплексів.

3 початку 80-х років клен гостролистий (Acer platanoídes L.) є одним із основних видів, які використовують під час створення зелених насаджень у населених містах Польщі, Болгарії, Естонії, Латвії, Литви, Казахстану (Levon, 2008). Рядові насадження 3 клена гостролистого (Acer platanoídes L.) на вулицях Білорусі та Росії набувають дедалі більшої популярності у 90-х роках минулого століття (Logginov, 1989). Водночас створюються насадження клена гостролистого (Acer platanoídes L.) в населених містах України, зокрема в Житомирі.

На сьогодні частка участі представників роду Acer L. в зелених насадженнях міст України змінюється від 10 до $35 \%$. Отже, вивчення еколого-естетичної ролі клена гостролистого (Acer platanoídes L.) та клена ясенелистого (Acer negundo L.) в сучасних урбокомплексах за умови змінення клімату та збільшення техногенного навантаження $є$ своєчасним та актуальним.

Мета дослідження - визначити екологічну та естетичну роль видів: клен гостролистий (Acer platano- ídes L.) та клен ясенелистий (Acer negundo L.) роду Клен (Acer L.) у зелених насадженнях Житомира.

Об'єкт досліджень - зелені насадження 3 участю видів клен гостролистий (Acer platanoídes L.) та клен ясенелистий (Acer negundo L.) роду Клен (Acer L.) у Житомирі.

\section{Постановка завдання:}

1. Визначити кількісну участь екземплярів клена гостролистого (Acer platanoídes L.) та клена ясенелистого (Acer negundo L.) у зелених насадженнях Житомира;

2. Оцінити фітосанітарний стан дерев клена гостролистого (Acer platanoídes L.) та клена ясенелистого (Acer negundo L.);

3. Визначити поширення дрібного фізіологічно активного коріння клена гостролистого (Acer platanoídes L.) в зелених насадженнях Житомира.

4. Проаналізувати еколого-естетичну роль дерев клена гостролистого (Acer platanoídes L.) та клена ясенелистого (Acer negundo L.) в зелених насадженнях Житомира.

Методика дослідження. Дослідження проводили у 2017-2018 рр. Під час дослідження поширення фізіологічно активних коренів використовували метод поступового взяття грунту шурфами (Gordienko, Muyrer \& Kovalevckiy, 2000). Брали приблизно 10 модельних дерев дерев клена гостролистого (Acer platanoídes L.) та клена ясенелистого (Acer negundo L.). Закладали грунтовий шурф $0,5 \times 0,5$ м. Корені вивчали за шарами $0-10$; 10-20; 20-30; 30-40; 40-50; 50-60; 60-70; 70-80; 80-90; 90-100 см. Корені вибирали з монолітів. У лабораторії корені мили, сортували на фракції за товщиною від 0,02,0 мм, висушували до повітряно-сухого стану і зважували на технічних терезах із точністю до 0,1 г.

Визначення частки участі в зелених насадження представників клена гостролистого (Acer platanoídes L.) та клена ясенелистого (Acer negundo L.) проводили згідно 3 "Інструкцією з технічної інвентаризації зелених насаджень у містах та селищах міського типу України" (Nakaz № 226, 2001). Визначення перспективності використання видів клена гостролистого (Acer platanoídes L.) та клена ясенелистого (Acer negundo L.) в системі озеленення Житомира проводили концептуальним методом.

Дослідження виконували маршрутним методом на вулицях Покровська, Героїв Небесної Сотні, Космонавтів, ім. Т. Г. Шевченка, ім. Лесі Українки, ім. С. П. Корольова, майдан Польовий та проспект Миру.

Результати дослідження. За даними наших досліджень у насадженнях Житомира клен гостролистий (Acer platanoídes L.) та клен ясенелистий (Acer negun$d o$ L.) представлені в рядових насадженнях уздовж автомобільних доріг, у групах на територіях, прилеглих до житлових будівель. Ми обстежили 11 екземплярів клена гостролистого (Acer platanoídes L.), які були солітерами, 186 дерев цього ж виду оглянуто в рядових насадженнях, 37 дерев у декоративних групах. Клен ясенелистий (Acer negundo L.) трапляється у групових насадженнях (обстежили 56 дерев). Подекуди він є у здичавілому стані у групах, які не піддавались догляду останні 10-15 років. У таких угрупуваннях обстежили 62 екземпляри.

За кількісним складом в окультурених насадженнях переважає клен гостролистий (Acer platanoídes L.) $44 \%$, друге місце посідає шароподібна ('Globosum') 
форма клена гостролистого - $37 \%$, всі інші форми, Друммонда (f. Drummondii), Шведлера (f. Schwedlerii), Роял Ред (f. Roal Red), представлені в декоративних групах і на присадибних ділянках у приватному секторі.

Одним із показників акліматизації та пристосованості до кліматичних умов $є$ накопичення фізіологічно активного коріння у верхніх (багатих органічними речовинами) шарах грунту. За нашими дослідженнями, дерева клена гостролистого (Acer platanoídes L.) основну масу дрібного коріння накопичують у верхньому 30сантиметровому шарі грунту (таблиця). На глибині 010 см зосереджено до $38 \%$ фізіологічно активного коріння, на глибині 10-20 см - до $26 \%$, на глибині 20$30 \mathrm{~cm}$ розташовується до $17 \%$ фізіологічно активного коріння.

Таблиця. Поширення фізіологічно активного коріння клена гостролистого в зелених насадженнях Житомира

\begin{tabular}{|c|c|c|c|}
\hline \multirow{2}{*}{$\begin{array}{c}\text { Глибина, } \\
\text { см }\end{array}$} & \multicolumn{3}{|c|}{ Вулиця: $(\%)$} \\
\cline { 2 - 4 } & $\begin{array}{c}\text { Шевченка, } \\
\text { вік 35 років }\end{array}$ & $\begin{array}{c}\text { Корольова, } \\
\text { вік 30 років }\end{array}$ & $\begin{array}{c}\text { героїв Небесної } \\
\text { Сотні, вік 35 років }\end{array}$ \\
\hline $0-10$ & 32 & 28 & 38 \\
\hline $10-20$ & 26 & 22 & 23 \\
\hline $20-30$ & 14 & 17 & 11 \\
\hline $30-40$ & 11 & 11 & 8 \\
\hline $40-50$ & 8 & 8 & 7 \\
\hline $50-60$ & 5 & 8 & 3 \\
\hline $60-70$ & 2 & 4 & 3 \\
\hline $70-80$ & 2 & 2 & 3 \\
\hline $80-90$ & 0 & 0 & 100 \\
\hline Разом & 100 & 100 & 3 \\
\hline
\end{tabular}

Коренева система клена гостролистого (Acer platanoídes L.) у віці 30-35 років проникає в грунт на глибину до 90 см. Бокові корені, які розташовуються ближче до поверхні - розгалужені та добре розвинені. За оптимальних умов зволоження грунту приріст бокових коренів за рік може сягати до 50 см.

Фітосанітарний стан дерев клена гостролистого (Acer platanoídes L.) у $83 \%$ досліджених екземплярів добрий, у 12 \% було виявлено механічні пошкодження, $5 \%$ дерев перебувають у пригніченому та фаутному стані (рисунок).

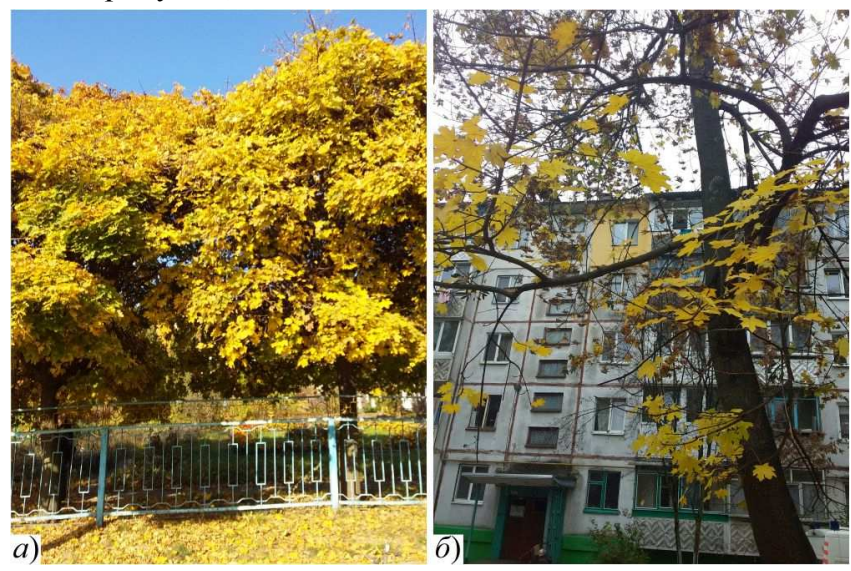

Рисунок. Фітосанітарний стан дерев клена гостролистого (Acer platanoídes L.) по вул. Шевченка та вул. Космонавтів у Житомирі

Більшість екземплярів клена гостролистого (Acer platanoídes L.) мають високі декоративні властивості, симетрично сформовані крони (див. рисунок), рівні стовбури - $83 \%$, у решти - (17\%) наявні вади стовбурів та крон. Рядові насадження з клена гостролистого мають високу естетичну привабливість та декоративність (див. рисунок, фото $a$ ).
Дерева клена гостролистого (Acer platanoídes L.) в зелених насадженнях Житомира повною мірою виконують фітомеліоративні функції, сприяють очищенню атмосферного повітря від пилу, газів та знижують шумове навантаження.

Дерева клена ясенелистого (Acer negundo L.) віком 30-35 років у групових насадженнях перебувають у задовільному стані. За фітосанітарними показниками 52 дерева із 56-ти $\epsilon$ в доброму стані, мають високу декортивність та естетичну привабливість. Водночас відзначається раннє омертвіння скелетних гілок у дерев у 25-30 років та формування порослевих насаджень із сплячих бруньок, що спричиняє здичавіння та прогрес інвазійних процесів. У насадженнях, за якими не проводили систематичного догляду, сформувались друга та третя порослеві генерації клена ясенелистого. Естетичний вигляд таких угруповань досить низький, зарості клена ясенелистого переважно багатоярусні. Щільно сформовані насадження заважають розвиватись іншим видам, конкуруючи як із інтродукованими видами, так iз аборигенними. На нашу думку, для поліпшення естетичної привабливості зелених насаджень за участі клена ясенелистого (Acer negundo L.) у Житомирі необхідно зберігати дорослі сформовані дерева, а здичавілі формувати, залишаючи чоловічі особини.

Водночас збережені в культурному стані та здичавілі представники клена ясенелистого (Acer negundo L.) повною мірою виконують фітомеліоративні функції, мають високий рівень стійкості до техногенного навантаження.

\section{Висновки:}

1. За кількісним складом в окультурених насадженнях переважає клен гостролистий (Acer platanoídes L.) - $44 \%$, друге місце посідає шароподібна ('Globosum') форма клена гостролистого - 37 \%, всі інші форми - $21 \%$. Коренева система клена гостролистого (Acer platanoídes L.) у віці 30-35 років проникає в грунт на глибину до 90 см. Фітосанітарний стан дерев клена гостролистого (Acer platanoídes L.) у $83 \%$ досліджених екземплярів добрий, у $12 \%$ було виявлено механічні пошкодження, $5 \%$ дерев перебувають у пригніченому та фаутному стані. Дерева клена гостролистого (Acer platanoídes L.) в зелених насадженнях Житомира повною мірою виконують еколого-естетичні та фітомеліоративні функції, сприяють очищенню атмосферного повітря від пилу, газів та знижують шумове навантаження.

2. Дерева клена ясенелистого (Acer negundo L.) віком 3035 років у групових насадженнях перебувають у задовільному стані. За фітосанітарними показниками $95 \%$ $\epsilon$ в доброму стані, мають високу декортивність та естетичну привабливість. Водночас відзначено раннє омертвіння скелетних гілок у дерев у 35-40 років та формування порослевих насаджень із сплячих бруньок, що спричиняє викликає здичавіння та прогрес інвазійних процесів. Естетичний вигляд таких угруповань досить низький. Водночас, за нашими даними, всі досліджувані екземпляри клена ясенелистого (Acer negundo L.) повною мірою виконують фітомеліоративні функції та мають високий рівень стійкості до техногенного навантаження.

\section{Перелік використаних джерел}

Gordienko, M. I., Muyrer, V. M., \& Kovalevckiy, S. B. (2000). Metodychny vkazivky do vyvchenna ta doslidgenna licovyx kyltyr. Kyiv: NAU, 56 p. [In Ukrainian]. 
Kalinichenko, O. A. (2003). Dekoratyvna dendrologia. Kyiv: Nauka, 197 p. [In Ukrainian].

Kochno, M. A. (1967). Introdykcia vidov klena in Ukraine. Butten. $G B C, 65,23-29$. [In Russian].

Kochno, M. A. (1970). Itogy i teoretycheskie osnovy introdykcii v Ukraine vydov roda Acer L. Abstract of Doctoral Dissertation for Biology Sciences (06.03.01 - Forest Crops and Phytomelioration). Kyiv, 38 p. [In Russian].

Kochno, M. A., \& Kuznetcov, S. I. (2000). Pro koncepciy mobilizacii cvitovych dendrologichnych recyrciv dla introdykcii in Ukraine. Introdykcia $i$ zelene bydivnyctvo, 83-89. [In Ukrainian].

Kochno, M. A., Dorochenko, O. K., \& Chyprina, P. Y. (1975). Introdykovani dereva ta kychi livoberezhnych chastyn Polissa ta
Lissostepy Ukraine. Introdykcia ta aklimatizachia roslun in Ukraine, 7, 27-41. [In Ukrainian].

Levon, F. M. (2008). Zeleni nasadgenna $v$ antropogennomy transformovanomy seredovychi. Kyiv: NNC IAE, 364 p. [In Ukrainian].

Logginov, V. B. (1989). Introdykcionnoe obogaschenie vidovogo sostava lesnych kyltyr (na primere Pravoberezhnoy Lesostepu v Ukraine). Abstract of Doctoral Dissertation for Biology sciences (06.03.01 - Forest Crops and Phytomelioration). Kyiv, 48 p. [In Russian].

Nakaz № 226. (2001). Derzhavnogo komitety bydivnictva, architektyru ta zhitlovoi politiki "Instrykcia z tehnichnoi inventarizacii zelenuch nasadgen y mistach i inchih naselenuch punktach Ukrainy" vid 24.12.2001. [In Ukrainian].

S. I. Matkovska, M. M. Svitelsky, A. V. Ishchuk, T. V. Pinkina, M. I. Fedyucka, V. D. Solomatina Zhytomyr National Agroecological University, Zhytomyr, Ukraine

\section{ENVIRONMENTAL ROLE OF REPRESENTATIVES OF ACER L. IN GREEN APPROXIMATES OF ZHYTOMIR}

Representatives of the family Maple (Acer L.) are mainly introduced to Ukraine predominantly from China, Japan, Korea and America. In order to plant greenery of human settlements in China, they were still used in 16-17 bands. In Japan, maples are used in landscaping of urbo-complexes from the 17th and 18th centuries, and have gained popularity in greening, along with sakurah, in the modern industrial cities of this country. The introduction of maples into Ukraine began in the 19th century from the East Asian species, later American maple species were imported into Ukraine, more than 30 ornamental species of maples are used in modern landscaping of our country. The purpose of the research is to determine the ecological and aesthetic role of species: acroleum maple (Acer platanoídes L.) and maple of the eggplant (Acer negundo L.) of the genus Maple (Acer L.) in green plantations of Zhytomyr. The research was conducted in 2017-2018. The research was conducted by the route method on the streets of Pokrovskaya, Heroes of Heavenly Hundreds, Cosmonauts, them. T. G. Shevchenko, them. Lesia Ukrainka, them. SP Koroleva, Field Square, and Prospect Mira. Results of researches: 1 . The quantitative composition in cultivated plantations is dominated by the maple acrosive (Acer platanoídes L.) $-44 \%$, the second place is globose ('Globosum'), the shape of the acute maple $-37 \%$, all other forms $-21 \%$. The root system of the acute (Acer platanoídes L.) maple tree at the age of 30-35 years penetrates into the soil to a depth of $90 \mathrm{~cm}$. Phytosanitary condition of the maple trees of acrosophilic (Acer platanoídes L.) in $83 \%$ of investigated specimens was good, in $12 \%$ mechanical damage was detected, $5 \%$ of trees were in suppressed and fattening condition. The plantain trees (Acer platanoídes L.) in green plantations of the city of Zhytomyr fully perform ecological, aesthetic and phytomeliorative functions, help to clean the air from dust, gases and reduce noise load. 2. Acer negundo L. trees in the age group of 30-35 years in grouped landings are in satisfactory condition, $95 \%$ of phytosanitary indicators are in good condition, have high decorative and aesthetic attractiveness. At the same time, there is an early neuronization of the skeletal branches in the trees in the 35-40 years, and the formation of sparse plantations from sleeping kidneys, which in turn causes the indiscretion and progress of the invasive processes. The aesthetic appearance of such groups is quite low. At the same time, according to our data, all investigated specimens of the maple germ (Acer negundo L.) fully perform phytomeliratory functions and have a high level of resistance to man-made load.

Keywords: ecological role; aesthetic appearance; eggplant maple (Acer negundo L.); maple is acute (Acer platanoídes L.); introduction. 